\title{
The Relatedness between Hepatitis B Virus from Non-Papuan Blood Donors in Jayapura and the Papuan Clusters
}

\author{
JUNIASTUTI $^{1 *}$, VICTOR EKANUGRAHAPUTRA $^{2}$, MOCHAMAD AMIN $^{3}$, \\ NI MADE MERTANIASIH ${ }^{1}$, AND MARIA INGE LUSIDA ${ }^{1,3}$
}

\author{
${ }^{I}$ Department of Microbiology, Faculty of Medicine, Universitas Airlangga, Jalan Mayjen Prof. Dr. Moestopo 47, \\ Surabaya 60131, Indonesia; ${ }^{2}$ Department of Microbiology, Faculty of Medicine, Universitas Cendrawasih, \\ Abepura Campus, Jalan Sentani-Abepura, Jayapura 99351, Indonesia; \\ ${ }^{3}$ Institute of Tropical Disease, Universitas Airlangga, Jalan Mulyorejo, Surabaya 60115, Indonesia
}

\begin{abstract}
The genotypes (A-H) and subtypes (adw2, adw4, adrq-, adrq+, ayw1-4, ayr) of HBV show distinct geographical distributions, which have been associated with anthropological history. The novel finding of the HBV subgenotypes C6 and D6 from Papuans formed a specific cluster distinct from the previous HBV subgenotypes C1-C5 and D1-D5. In this study we determined the most recent genotype-subtype patterns of the HBV from non-Papuan blood donors who live in Jayapura and their phylogenetic relatedness, especially with the Papuan clusters. Fifteen HBsAg-positive serums were obtained from non-Papuan blood donors including from people in Java (46.7\%), Maluku (26.7\%), Sulawesi (20\%) and East Nusa Tenggara (6.7\%). S gene of all HBV serum isolates were partially sequenced and analyzed. Most HBV isolates $(53.3 \%)$ were classified as genotype B, followed by genotype C (26.7\%) and D (20.0\%). The subtype $a d w 2(33.3 \%)$ was predominant, followed by $a d r q+(26.7 \%)$ and aywl/ayw2 (20.0\%). All HBV isolates with subtype $a d w 2$ and ayw1 belonged to genotype B, while $a d r q+$ belonged to genotype $\mathrm{C}$ and ayw2 belonged to genotype D. The most predominant HBV genotype-subtype (B/adw2) was consistent with the ethnic background (mostly from Java people). Nevertheless, based on the phylogenetic relatedness, many non Papuan isolates (40\%) were classified into HBV/C6 and HBV/D6 of the Papuan clusters. Other isolates were classified into HBV/C1, HBV/B3 and HBV/B7. In conclusion, many HBV isolates from non-Papuans in Jayapura belonged to the Papuan clusters, but others had different genotype-subtype patterns with frequencies dependent on ethnicity.
\end{abstract}

Key words: hepatitis B virus, genotypes, subtypes, phylogenetic relatedness

Hepatitis B virus (HBV) infection is a serious global health problem. In 2000, Core Working Party for AsiaPasific Consensus on Hepatitis B and C reported that Indonesia belonged to the moderate-to-high hepatitis $\mathrm{B}$ endemic region (Khan et al. 2004). Carrier rates among blood donors ranged from 2.1 to $9.5 \%$ in 11 large cities and even higher at $17.5 \%$ in Jayapura, the Papua Province (Sastrosoewignjo et al. 1991).

Eight genotypes (from A to $\mathrm{H}$ ) of $\mathrm{HBV}$ have been identified worldwide, based on a divergence of $8 \%$ or more of the complete genome, and more than $4 \%$ at the level of the S gene (Okamoto et al. 1988; Norder et al. 1994; Magnius and Norder 1995; Stuyver et al. 2000; ArauzRuiz et al. 2002; Kramvis et al. 2005). Nine HBV subtypes (adw2, adw4, adrq-, adrq+, ayw1-4, ayr) were defined by two mutually exclusive determinant pairs, $d / y$ and $w(w 1-4) / r$, and a common determinant ' $a$ ' of HBsAg (Magnius and Norder 1995; Kramvis et al. 2005). The HBV isolates of different genotypes and subtypes show different geographical distributions, virological characteristics, and possibly clinical outcomes (Kao et al. 2000; Orito et al. 2001; Kao 2002; Kidd-Ljunggren et al. 2002). They could also provide historical information on the migration pattern of the ancestor of local population (Magnius and Norder 1995; Orito et al. 2001)

The subgenotypes have been identified for certain HBV genotypes. HBV/C has been classified into six subgenotypes (C1 to C6) (Sugauchi et al. 2001; Huy et al. 2004; Chan et al. 2005; Sakamoto et al. 2006; Lusida et

"Corresponding author: Phone:+62-31-5030252 ext. 159 Fax: +62-31-5022472, E-mail: koeraisindewi@yahoo.co.id al. 2008), HBV/D into six subgenotypes (D1 to D6) (Norder et al. 2004; Bozdayi et al. 2005; Banerjee et al. 2006; Schaefer 2007; Lusida et al. 2008) and HBV/B into seven subgenotypes (B1 to B7) (Sugauchi et al. 2001; Nagasaki et al. 2006; Sakamoto et al. 2006; Sakamoto et al. 2007; Nuraeny et al. 2008). As HBV genotypes, the HBV subgenotypes seem to be associated with their geographical distributions.

Previous studies of genotype-subtype distributions of HBV in Jayapura, especially those from Papuans, reported that C/adr was predominant (Sastrosoewignjo et al. 1991; Mulyanto et al. 1997; Lusida et al. 2008). In 1997 Mulyanto assumed that the Papuan ancestor came from New Caledonia (HBV/C3), where $a d r$ is largely found. Besides, based on anthropological origin, Papuans resemble Australian Aborigines, because the mainlands of the two tribes were one continent before it was separated 7000 years ago (Sugauchi et al. 2001). However, Sugauchi et al. (2001) found the C/ayw3 isolates from Australian Aborigine (HBV/C4), which had a different HBV subtype from that of Papuans. Recently, Lusida et al. (2008) reported that most HBV isolates from Papuan blood donors in Jayapura belonged to the novel C subgenotype (HBV/C6), separated from the previous HBV C subgenotypes, including the New Caledonia (HBV/C3) and Australia clusters (HBV/C4). They also reported that other Papuan isolates belonged to the novel HBV D subgenotype, namely D6.

The aim of this study was to determine the most recent genotype-subtype patterns of HBV based on part of the $\mathrm{S}$ gene in HBsAg-positive blood donors from non-Papuans who live in Jayapura, the Papua Province. Their 
phylogenetic relatedness was also analyzed, especially with HBV of Papuan clusters.

\section{MATERIALS AND METHODS}

Collection of Field Samples. Serum samples were taken from non-Papuan blood donors who visited the Blood Transfusion Unit-Indonesian Red Cross in Jayapura from July 2006 to September 2006, and were screened for HBsAg by using the immunochromatography method (entebe HBsAg strip, Hepatika Laboratory, Mataram). All serum samples were stored at $-20{ }^{\circ} \mathrm{C}$ until transported to the Institute of Tropical Disease in Surabaya, where they were stored at $-80^{\circ} \mathrm{C}$. Ethical clearance of this study was obtained from the ethics committee of the Faculty of Medicine, Airlangga University in Surabaya, Indonesia. All blood donors signed an agreement to participate in this study.

Viral DNA Extraction, PCR Amplification and Sequencing. Genomic DNA of HBV was extracted from serum samples by using the DNA zol reagent (Invitrogen) following the manufacturer's guidelines. The extracted DNA was used as a template for the amplification of the respective gene regions. PCRs were performed with the PCR mastermix (Fermentas). The reactions contained $25 \mu \mathrm{L}$ PCR mastermix, $10 \mathrm{~mL}$ DNA and $0.5 \mu \mathrm{L}$ of each primer with a concentration of $20 \mathrm{pmol} \mu \mathrm{L}^{-1}$, in a total reaction volume of $50 \mu \mathrm{L}$. The thermocycling conditions included a 5-min denaturation step of $94^{\circ} \mathrm{C}$; followed by 40 cycles of $1 \mathrm{~min}$ at $94^{\circ} \mathrm{C}, 1 \mathrm{~min}$ at $55^{\circ} \mathrm{C}$ and 2 min at $72{ }^{\circ} \mathrm{C}$. Partial S gene was amplified in the first round by using primers P7 (5'-GTG GTG GAC TTC TCT CAA TTT TC-3', nt 256 to 278 ) and P8 (5' - CGG TAW ${ }^{[\mathrm{A} / \mathrm{T}]}$ AAA GGG ACT CAM ${ }^{[A / C]}$ GAT-3', nt 796 to 776). If the first round PCR was negative, therefore the second round PCR was performed by using primers HBs1 (5'-CAA GGT ATG TTG CCC GTT TG-3', nt 455 to 474) and HBs2 (5'-AAA GCC CTG CGA ACC ACT GA-3', nt 713 to 694) (Lusida et al. 2003). PCR products were sequenced using the Big Dye Terminator v1.1 Cycle Sequencing Kit (Applied Biosystems, USA) and ABI Prism 310 Genetic Analyzer (Perkin Elmer).

Analysis of Sequence. Sequence analysis was performed with Genetyx-Mac version 9 (Software Development Co., Ltd., Tokyo, Japan). The HBV genotype of the samples was determined based on the homology percentage of $>96 \%$ in the S gene (Magnius and Norder 1995; Arauz-Ruiz et al. 1997). After aligining the sequences of the HBV nucleotide and converting it into amino acid sequences, the HBV subtype of the samples was assigned by analyzing the amino acid substitutions at positions 122, 127, 134, 159, 160, 177 in the $S$ gene (Okamoto et al. 1988; Norder et al. 1994; Kramvis et al. 2005). The phylogenetic tree was constructed by means of Unweighted Pair Group Method using the clustering of Arithmetic averages (UPGMA).

\section{RESULTS}

A total of $15 \mathrm{HBsAg}$-positive serum was obtained from non-Papuan blood donors (14 male and 1 female; age 18-52). The blood donors were people from Java (46.7\%), Maluku (26.7\%), Sulawesi (20\%) and East Nusa Tenggara (6.7\%) living in Jayapura. A sequence analysis of part of the $\mathrm{S}$ gene of HBV serum isolates was performed (Table 1).

Table 1 Ethnics of non-Papuan blood donors in Jayapura

\begin{tabular}{lc}
\multicolumn{1}{c}{$\begin{array}{c}\text { Ethnics of non } \\
\text { Papuan blood donors }\end{array}$} & Number \\
\hline Java & 7 \\
Sulawesi & 3 \\
Maluku & 4 \\
East Nusa Tenggara & 1 \\
Total & 15 \\
\hline
\end{tabular}

The distribution of the HBV genotypes among the 15 serum in non-Papuans indicated that most isolates $(53.3 \%)$ were classified into genotype $\mathrm{B}$, followed by genotype $\mathrm{C}$ (26.7\%) and D (20\%) (Table 2).

The HBV subtypes were determined by aligning $15 \mathrm{HBV}$ sequences from non-Papuans and 70 reported HBV sequences (A-H genotypes) including HBV of the Papuan clusters, at the amino acids positions $117-180$ of the $\mathrm{S}$ gene (Fig 1). By analyzing amino acid substitutions at positions $122,127,134$ and 160, it was found that the subtype $a d w 2$ (33.3\%) was predominant, followed by $\operatorname{adr}(26.7 \%)$, and aywl/ ayw2 (20\%) (Table 2). All isolates with $a d r$ subtype had alanine (A) at position 159 and valine (V) at position 177 in $\mathrm{HBV}$, and this combination is considered important for the $q$ determinant (Fig 1).

All HBV isolates with $a d w 2$ and aywl belonged to genotype $\mathrm{B}$, subtype $a d r(q+)$ belonged to genotype $\mathrm{C}$, and ayw2 to genotype D (Table 2). No C/adrq-isolates were found here.

The genotype subtype patterns of HBV from various ethnics of non-Papuan blood donors obtained in Jayapura, were summarized in Table 3 . HBV B/adw2 was predominant in Javanese, followed by B/ayw1 or $\mathrm{C} / a d r q+$. HBV B/adw2 was also more than B/aywl in Sulawesi people. HBV D/ ayw2 was commonly found in Moluccans, followed by $\mathrm{C} / a d r q+$, but only $\mathrm{HBV} \mathrm{C/adrq+}$ was found in East Nusa Tenggara people.

The phylogenetic analysis of part of the S region (nt 503 to 694) of the HBV genome revealed that many HBV isolates (40\%) from non-Papuans (Javanese and Molluccans) were classified into Papuan clusters, such as HBV/C6 (6NP, 27NP and 49NP) and HBV/D6 (7NP, 25NP, 26NP). Some isolates from Javanese and Sulawesi people (30NP, 37NP and 57NP) were classified into HBV/B3. Two isolates from Javanese (9NP and 18NP) were classified into HBV/B7 (Alor, East Nusa Tenggara). One isolate from East Nusa Tenggara people

Table 2 HBV genotype and subtype distribution patterns from non-Papuan blood donors in Jayapura

\begin{tabular}{lc}
\hline HBV Genotypes/subtypes & $\begin{array}{c}\text { Number of cases in } \\
\text { non-Papuan blood donors }\end{array}$ \\
\hline B/adw 2 & 5 \\
B/ayw1 & 3 \\
Cladrq+ & 4 \\
D/ayw2 & 3 \\
Total & 15 \\
\hline
\end{tabular}



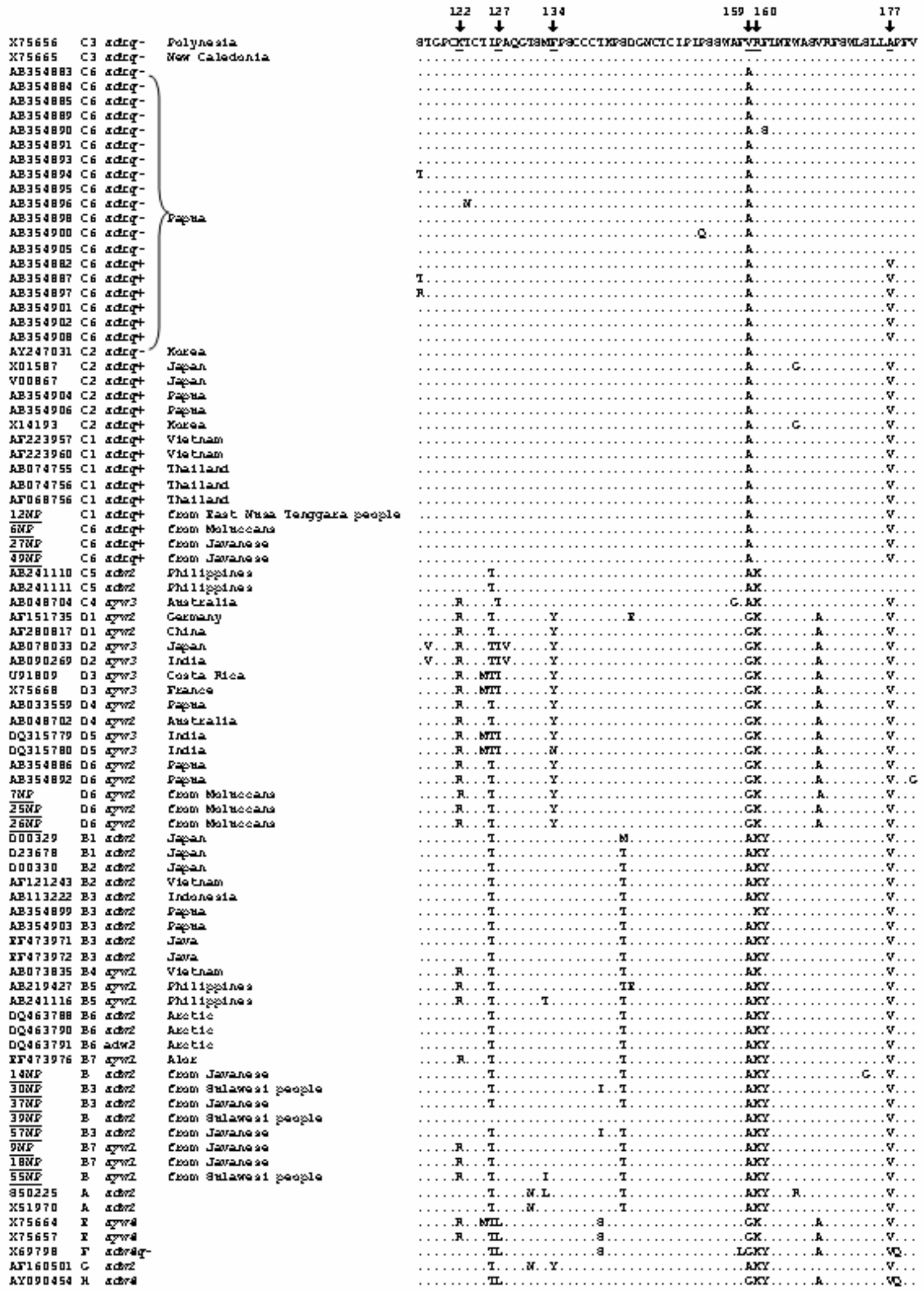

Fig 1 Alignment of amino acid sequences of HBV isolates from 15 non-Papuan blood donors in Jayapura, Indonesia (code: NP) and 70 reported sequences of genotypes A to $\mathrm{H}$ including the Papuan clusters, C6 and D6 (Lusida et al. 2008). The sequences correspond to amino acids 117 to 180 of the $\mathrm{S}$ gene. 
Table 3 HBV genotype-subtype patterns from various ethnics of non-Papuan blood donors in Jayapura

\begin{tabular}{lccccr}
\hline $\begin{array}{l}\text { Ethnics of } \\
\text { non-Papuan } \\
\text { blood donors }\end{array}$ & \multicolumn{4}{c}{ No. of cases } & Total \\
\cline { 2 - 5 } & $\mathrm{B} /$ adw2 & $\mathrm{B} /$ ayw1 & C/adrq+ & D/ayw2 & \\
\hline Java & 3 & 2 & 2 & & 7 \\
Maluku & & & 1 & 3 & 4 \\
Sulawesi & 2 & 1 & & & 1 \\
East Nusa Tenggara & & & 1 & 15 \\
\hline
\end{tabular}

(12NP) was classified into HBV/C1 (South East Asia). Some $\mathrm{HBV} / \mathrm{B}$ isolates from Javanese and Sulawesi people (14NP, $39 \mathrm{NP}$ and 55NP) were not definitely classifiable on the basis of the partial S gene sequencing alone. All HBV/C isolates were from non-Papuans separated from Far East Asia (HBV/ C2), New Caledonia-Polynesia (HBV/C3), Australia (HBV/C4) and the Philippines (HBV/C5) clusters (Fig 2).

\section{DISCUSSION}

Papua island is in the eastern part of Indonesia with Papuans as its native people. Beside the natives, many other ethnic groups in Indonesia, like Javanese, Sumatrans, Moluccans, and people from Sulawesi and East Nusa Tenggara descent live in Papua. Here, HBV isolates from non-Papuans who live in Jayapura, Papua province, were presented.

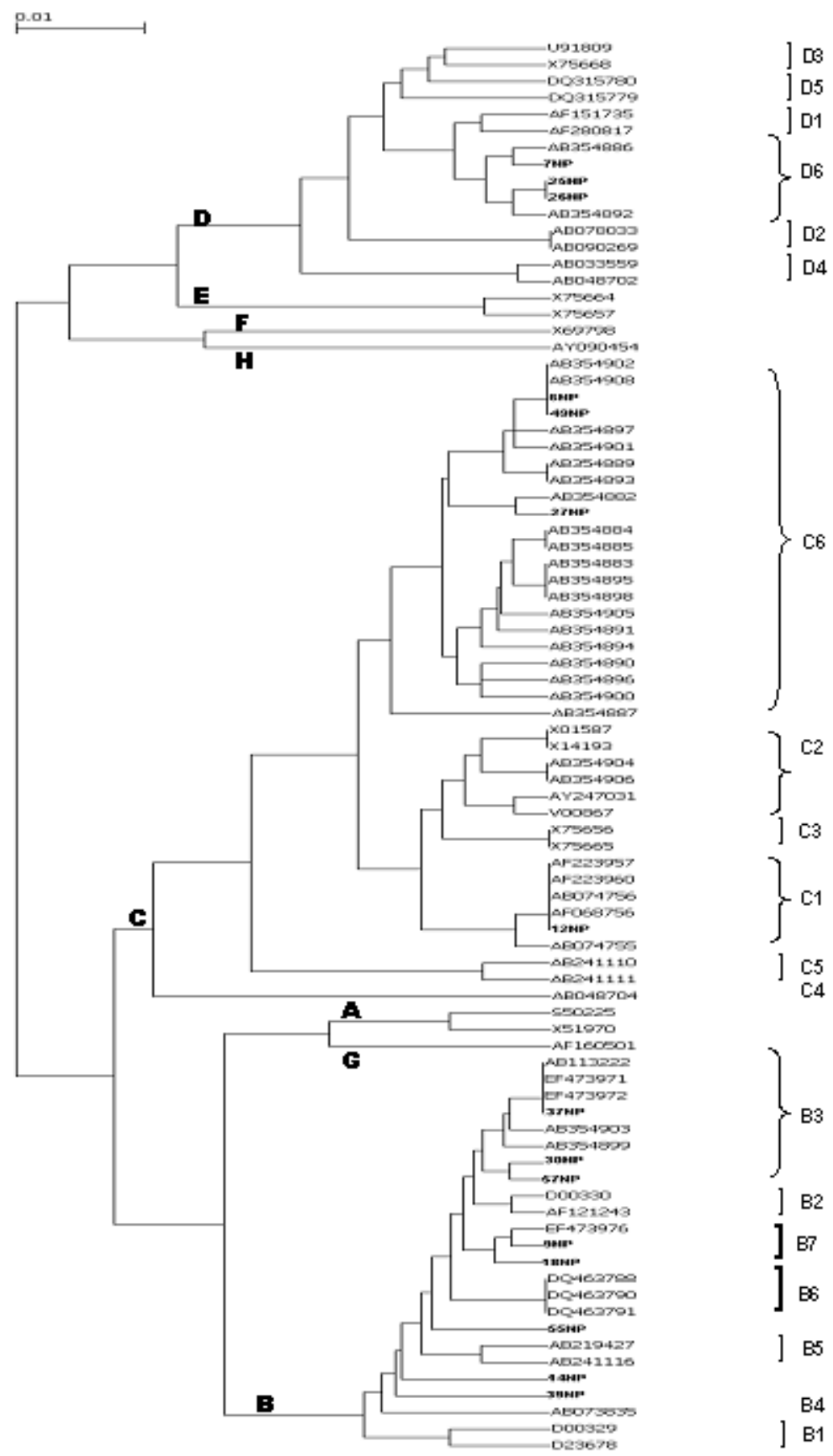

Fig 2 Phylogenetic analysis of HBV isolates obtained from 15 non-Papuan blood donors (code: NP) compared with the reported of all genotypes and subgenotypes of $\mathrm{HBV}$, including the subgenotypes C6 and D6 of the Papuan clusters (Lusida et al. 2008); on the basis of the partial S genes (503-694). The genotypes are indicated on the branches and the subgenotypes are on the right. 
This study demonstrated that most $(53.3 \%) \mathrm{HBV}$ isolates from non-Papuan blood donors were classified into genotype $\mathrm{B}$, followed by genotype C (26.7\%) and D (20\%) (Table 2). No $\mathrm{HBV}$ isolates were found with genotypes A, E, F, G or H from the non-Papuans. Each HBV genotype has characteristic geographic distribution. In some cases, differences in the distribution of the genotypes can be found within a single country, as has been observed in China, India, USA and Indonesia as well. The genotype distributions can be influenced by the ethnic background and the country origin of the individual carriers of the virus (Kramvis et al. 2005). Indonesia is a country that has more than 300 ethnic groups and over 250 languages (Sofro 1982). It is characterized by its national motto - "Bhinneka Tunggal Ika" or "unity in diversity". The diversity in this country can now be assessed also in the light of the HBV genotypes. In the western part of Indonesia, the HBV genotype B was predominant, while the HBV genotype $\mathrm{C}$ was predominant in the eastern part of Indonesia, especially in Papua (Sastrosoewignjo et al. 1991; Mulyanto et al. 1997; Usuda et al. 1999; Lusida et al. 2008). The results revealed that most predominant HBV genotype of non-Papuans isolates was genotype B. The samples were mostly obtained from people of the western part of Indonesia (Javanese) (Table 1 and 3). HBV genotype B was also found more in Sulawesi people, which was consistent with the report of Sastrosoewignjo et al. (1991). Like other regions in most developing countries where vertical transmission is predominant, the distributions of HBV genotypes-subtypes in Papua seemed to be dependent on ethnicity.

The subtype $a d w 2(33.3 \%)$ was the most predominant in all HBV isolates from non-Papuan blood donors, followed by $a d r q+(26.7 \%)$ and ayw1/ayw2 (20\%) (Table 2). Each HBV subtype markedly varied in different geographical regions in Indonesia. The most predominant HBV subtype in the western part of Indonesia, such as Java, is $a d w$ (Mulyanto et al. 1997). Beside that, they concluded that Sulawesi was the mixed HBV subtype zone, including $a d w$. It was consistent with our results that the subtype $a d w 2$ was mostly obtained from Javanese, followed by Sulawesi people (Table 3). Nevertheless, it was different with the predominance of the $a d r$ subtype in Papuans. Sastrosoewignjo et al. (1991) showed that $50 \%$ of $14 \mathrm{HBV}$ isolates from blood donors in Jayapura belonged to the subtype $a d r$. Mulyanto et al. (1997) also reported that $76.9 \%$ of the 13 isolates of adult population of Papuan in Jayapura belonged to the subtype $a d r$. Lusida et al. (2008) found that $85.2 \%$ of the 23 isolates from blood donors (mostly Papuans) in Papua belonged to the subtype $a d r$, too. Our results confirmed the difference of the most predominant HBV subtype from Papuans with non-Papuans even though they lived in the same places.

All HBV isolates with subtype $a d w 2$ and $a y w 1$ belonged to genotype $\mathrm{B}, a d r q+$ to genotype $\mathrm{C}$ and $a y w 2$ to genotype D. No HBV C/adrq- isolates were found here. This was consistent with the HBV genotypes and subtypes relationship. In comparison to our results, the subtype $a d r$ is rarely found in genotype $\mathrm{B}$, subtype $a d w 2$ can be found in genotypes A, C, F, G and subtype ayw2 can be found in genotypes A and C (Kramvis et al. 2005).
By analyzing the phylogenetic relatedness on part of the $\mathrm{S}$ gene, it was found that many HBV isolates (40\%) from non-Papuans (Javanese and Moluccans) belonged to the Papuan clusters, HBV/C6 (6NP, 27NP and 49NP) and HBV/ D6 (7NP, 25NP, 26NP). Surprisingly, it seemed that there could be a horizontal transmission of HBV from Papuans to nonPapuans living in Papua, in an adequate number. Two isolates from Javanese and one isolate from Sulawesi people (30NP, 37NP and 57NP) were classified into HBV/B3 (Java and Papua). The reported HBV/B3 isolates from Papua by Lusida et al. (2008), were possibly obtained from Javanese living in Papua. Two isolates from Javanese (9NP and 18NP) were classified into HBV/B7 (Alor, East Nusa Tenggara). The possible reason was the fact that there were many East Nusa Tenggara people living in Papua, especially in transmigration areas. Besides, one isolate (12NP) from East Nusa Tenggara people was classified into HBV/C1 (South East Asia). Again, it might be caused by horizontal transmission, because there were many Thailand seamen who came to Papua. Interestingly, some $\mathrm{HBV} / \mathrm{B}$ isolates from Javanese and Sulawesi people (14NP, $39 \mathrm{NP}$ and 55NP) were not definitely classifiable into the previous subgenotype B (B1-B7). They had possibly distinct clusters which reflected the specificity of the ethnicity in the HBV distributions, but futher investigation about other regions, such as the pre-S or even the whole region of HBV DNA is needed. Finally, all HBV/C isolates from non-Papuans are separated from Far East Asia (HBV/C2), New CaledoniaPolynesia (HBV/C3), Australia (HBV/C4) and the Philippines (HBV/C5) clusters (Fig 2). This confirmed that the existence of HBV genotypes-subtypes in Papua was unique.

Overall, it could be concluded that many HBV isolates from non-Papuans in Jayapura belonged to the Papuan clusters, but others had different genotype-subtype patterns which frequencies were dependent on ethnicity. There could be a domination of HBV from Papuans, but the existence of HBV from non-Papuans must be considered as another important role to determine the circulation of the HBV genotypes-subtypes in Papua.

\section{ACKNOWLEDGEMENTS}

The authors are grateful to Regina H. Hutabarat, Head of the Blood Transfusion Unit-Indonesia Red Cross, Jayapura, Yoes Prijatna Dachlan, Head of Institute of Tropical Diseases for his cooperation; Izumi, Ni Nyoman Tri Puspaningsih and Eduardus Bimo for their invaluable supports; and Koen Poedjiati for her technical assistance. We also deeply appreciate the blood donors at the Blood Transfusion UnitIndonesia Red Cross, Jayapura, who had given their blood in this study. This study was supported by a grant from the collaboration of Risbiniptekdok and the Committee of Research and Development, Departement of Health, Indonesia.

\section{REFERENCES}

Arauz-Ruiz P, Norder H, Robertson BH, Magnius LO. 2002. Genotype $\mathrm{H}$ : a new Amerindian genotype of hepatitis B virus revealed in Central America. J Gen Virol 83:2059-73. 
Arauz-Ruiz P, Norder H, Visoná KA, Magnius LO. 1997. Molecular epidemiology of hepatitis B virus in Central America reflected in the genetic variability of the small $\mathrm{S}$ gene. J Infect Dis 176:851-8.

Banerjee A, Kurbanov F, Sibnarayan D, Chandra PK, Tanaka Y, Mizokami M, Chakravarty R. 2006. Phylogenetic relatedness and genetic diversity of hepatitis B virus isolates in Eastern India. J Med Virol 78:1164-74.

Bozdayi G, Turkyilmaz AR, Idilman R, Karataylii E, Rota S, Yurdaydin C, Bozdayi AM. 2005. Complete genome sequence and phylogenetic analysis of hepatitis B virus isolated from Turkish patients with chronic HBV infection. J Med Virol 76:76-481.

Chan HLY, Tsui SKW, Tse CH, Ng YET, An TCC, Yuen L, Bartholomeusz A, Leung KS, Lee KH, Locarnini S, Sung JJY. 2005. Epidemiological and virological characteristics of 2 subgroups of hepatitis B virus genotype C. J Inf Dis 191:2022-33.

Huy TTT, Ushijima H, Quang VX, Win KM, Luengrojanakul P, Kikuchi K, Sata T, Abe K. 2004. Genotype C of hepatitis B virus can be classified into at least two subtribes. J Gen Virol 85:283-92.

Kao JH. 2002. Hepatitis B viral genotypes: clinical relevance and molecular characteristics. J Gastroenterol Hepatol 17:643-50.

Kao JH, Chen PJ, Lai MY, Chen DS. 2000. Clinical and virological aspects of blood donors infected with hepatitis B virus genotypes B and C. J Clin Microbiol 40:22-5.

Khan M, Dong JJ, Acharya SK, Dhagwahdorj Y, Abbas Z, Jafri W, Mulyono DH, Tozun N, Sarin SK. 2004. Hepatology issues in Asia: perspective from regional leaders. J Gastroenterol Hepatol 19:419-30.

Kidd-Ljunggren K, Miyakawa, Kidd AH. 2002. Genetic variability in hepatitis B viruses. J Gen Virol 83:1267-80.

Kramvis A, Kew M, François G. 2005. Hepatitis B virus genotypes. Vaccine 23:2409-23.

Lusida MI, Nugrahaputra VE, Soetjipto, Handajani R, Nagano-Fujii M, Sasayama M, Utsumi T, Hotta H. 2008. Novel subgenotypes of hepatitis $\mathrm{B}$ virus genotypes $\mathrm{C}$ and $\mathrm{D}$ in Papua, Indonesia. J Clin Microbiol 46:2160-6.

Lusida MI, Surayah, Sakugawa H, Nagano-Fujii M, Soetjipto, Mulyanto, Handajani R, Boediwarsono, Setiawan PB, Nidom CA, Ohgimoto S, Hotta H. 2003. Genotype and subtype analyses of hepatitis B virus (HBV) and possible co-infection of $\mathrm{HBV}$ and hepatitis $\mathrm{C}$ virus (HCV) or hepatitis D virus (HDV) in blood donors, patients with chronic liver disease and patients on hemodialysis in Surabaya, Indonesia. Microbiol Immunol 47:969-75.

Magnius LO, Norder H. 1995. Subtypes, genotypes and molecular epidemiology of the hepatitis B virus as reflected by sequence variability of the S-gene. Intervirology 38:24-34.

Mulyanto, Tsuda F, Karossi AT, Soewignjo S, Roestamsjah, Sumarsidi D, Trisnamurti RH, Sumardi, Surayah, Udin LZ, Melani-Wikanta, Kanai K, Mishiro S. 1997. Distribution of the Hepatitis B surface antigen subtypes in Indonesia: implications for ethnic heterogeneity and infection control measures. Arch Virol 142:2121-9.

Nagasaki F, Niitsuma H, Cervantes JG, Chiba M, Hong S, Ojima T, Ueno Y, Bondoc E, Kobayashi K, Ishii M, Shimosegawa T. 2006. Analysis of the entire nucleotide sequence of hepatitis B virus genotype $\mathrm{B}$ in the Philippines reveals a new subgenotypes of genotype B. J Gen Virol 87:1175-80.

Norder H, Couroucé AM, Coursaget P, Echevarria JM, Lee SD, Mushahwar IK, Robertson BH, Locarnini S, Magnius LO. 2004. Genetic diversity of hepatitis B virus strains derived worldwide: genotypes, subgenotypes, and HBsAg subtypes. Intervirology 47:289-309.

Norder H, Couroucé AM, Magnius LO. 1994. Complete genomes, phylogenetic relatedness and structural proteins of six strains of the hepatitis B virus, four of which represent two new genotypes. Virology 198:489-503.

Nuraeny N, Muljono H, Sudoyo H, Marzuki S. 2008. Genetic study of hepatitis B virus in Indonesia revelas a new subgenotype of genotype $B$ in east Nusa Tenggara. Arch Virol 153:1057-65.

Okamoto H, Tsuda F, Sakugawa H, Sastrosoewignjo RI, Imai M, Miyakawa Y, Mayumi M. 1988. Typing hepatitis B virus by homology in nucleotide sequence: comparison of surface antigen subtypes. J Gen Virol 69:2575-83.

Orito E, Ichida T, Sakugawa H, Sata M, Horiike N, Hino K, Okita K, Okanoue T, Iino S, Tanaka E, Suzuki K, Watanabe H, Hige S, Mizokami M. 2001. Geographical distribution of hepatitis B virus (HBV) genotype in patients with chronic HBV infection in Japan. Hepatology 34:590-4.

Sakamoto T, Tanaka Y, Orito E, Co J, Clavio J, Sugauchi F, Ito K, Ozasa A, Quino A, Ueda R, Sollano J, Mizokami M. 2006. Novel subtypes (subgenotypes) of hepatitis B virus genotypes B and C among chronic liver disease patients in the Philippines. J Gen Virol 87:1873-82.

Sakamoto T, Tanaka Y, Simmonetti J, Osiowy C, Berresen M, Koch A, Kurbanov F, Sugiyama M, Minuk G, McMahon J, Joh T, Mizokami M. 2007. Classification of hepatitis B virus genotype B into 2 major types based on characterization of a novel subgenotype in Arctic Indigenous population. J Infect Dis 196:1487-92.

Sastrosoewignjo RI, Sandjaja B, Okamoto H. 1991. Molecular epidemiology of hepatitis B virus in Indonesia. J Gastroenterol Hepatol 6:491-8.

Schaefer S. 2007. Hepatitis B virus taxonomy and hepatitis B virus genotypes. World J Gastroenterol 13:14-21.

Sofro ASM. 1982. Population genetic studies in Indonesia. [Dissertation]. Canberra: Australian National University.

Stuyver L, Gendt S de, Geyt C van, Zoulim F, Fried M, Schinazi RF, Rossau R. 2000. A new genotype of hepatitis B virus: complete genome and phylogenetic relatedness. J Gen Virol 81:67-74.

Sugauchi F, Mizokami M, Orito E, Ohno T, Kato H, Suzuki S, Kimura Y, Ueda R, Butterworth LA, Cooksley WGE. 2001. A novel variant genotype $\mathrm{C}$ of hepatitis $\mathrm{B}$ virus identified in isolates from Australian Aborigines: complete genome and phylogenetic relatedness. J Gen Virol 82:883-92.

Usuda S, Okamoto H, Iwanari H, Baba K, Tsuda F, Miyakawa Y, Mayumi M. 1999. Serological detection of hepatitis B virus genotypes by ELISA with monoclonal antibodies to type-specific epitopes in the preS2-region product. J Virol Methods 80:97-112. 